\title{
Manajemen Penjaminan Mutu dalam Meningkatkan Kedisiplinan Santri di MA Raudlatul Ulum Guyangan Pati
}

\author{
Aizzatin, Nur Uhbiyati, Musthofa \\ Universitas Islam Negeri Walisongo, Semarang, Indonesia \\ aizzatin97@gmail.com
}

\begin{abstract}
Improving student discipline is one way in quality assurance in Madrasah Aliyah Raudlatul Ulum Guyangan Pati. This study aims to : 1. Describe and analyze quality assurance planning in improving student discipline at MA Raudlatul Ulum Guyangan Pati 2. Describe and analyze the implementation of quality assurance in Madrasah Raudlatul Ulum Guyangan Pati 3. Describe and analyze the evaluation of quality assurance in Madrasah Aliyah Raudlatul Ulum Guyangan Pati.

This research is qualitative research, which aims to understand a phenomenon that is happening observed by researchers. In the discussion of this thesis is used a method that is descriptive analysis that is the method aims to know how the Principal and his staff guarantee the quality of madrasah by improving the discipline of students in Madrasah Aliyah Raudlatul Ulum Guyangan Pati.

In this research study that (1) Education quality assurance planning in improving discipline $M A$ (2) Implementation of quality assurance discipline (3) Evaluation of quality assurance of education.

From the results of the study, the author gave advice to educational institutions Raudlatul Ulum Guyangan Pati to maintain achievements that have not been achieved by madrasah, improve achievements that have not been achieved, cultivate a quality culture to advance madrasah, hold recruitment of teachers or educational personnel to succeed educational activities, and provide facilities or facilities and good learning infrastructure.
\end{abstract}

Keywords: Madrasah Quality Assurance, Discipline Improvement

\section{ABSTRAK}

Peningkatan kedisiplinan santri merupakan salah satu cara dalam penjaminan mutu di Madrasah Aliyah Raudlatul Ulum Guyangan Pati. Penelitian ini bertujuan untuk: (1) Mendeskripsikan dan menganalisis perencanaan penjaminan mutu dalam meningkatkan kedisiplinan santri 
di MA Raudlatul Ulum Guyangan Pati (2) Mendeskripsikan dan menganalisis pelaksanaan penjaminan mutu di Madrasah Raudlatul Ulum Guyangan Pati (3) Mendeskripsikan dan menganalisis evaluasi penjaminan mutu di Madrasah Aliyah Raudlatul Ulum Guyangan Pati. Penelitian ini merupakan penelitian kualitatif, yang bertujuan untuk memahami suatu fenomena yang sedang terjadi yang diamati oleh peneliti. Dalam pembahasan skripsi ini digunakan metode yang bersifat deskriptif analisis yaitu metode bertujuan untuk mengetahui bagaimana cara Kepala Sekolah dan para staf nya menjamin mutu madrasah dengan cara meningkatkan kedisiplinan santri di Madrasah Aliyah Raudlatul Ulum Guyangan Pati. Pada kajian penelitian ini bahwa (1) Perencanaan penjaminan mutu pendidikan dalam meningkatkan kedisiplinan MA (2) Pelaksanaan penjaminan mutu kedisiplinan (3) Evaluasi penjaminan mutu pendidikan. Dari hasil penelitian tersebut, penulis memberikan saran kepada lembaga pendidikan Raudlatul Ulum Guyangan Pati untuk mempertahankan prestasi-prestasi yang belum diraih oleh madrasah, meningkatkan prestasi-prestasi yang belum diraih, membudayakan budaya mutu untuk memajukan madrasah, mengadakan rekruitmen guru ataupun tenaga kependidikan untuk mensukseskan kegiatan pendidikan, dan menyediakan fasilitas ataupun sarana dan prasarana pembelajaran yang baik.

Kata Kunci : Penjaminan Mutu Madrasah, Peningkatan Kedisiplinan

\section{LATAR BELAKANG}

Manajemen sebagai sebuah disiplin ilmu sudah banyak dibincangkan dalam dunia Islam. Manajemen selama ini terkesan merupakan produk dari budaya barat, seolah tidak ada kontribusi Islam dalam disiplin tersebut. Persepsi seperti itu disebabkan oleh literatur, literatur manajemen yang digunakan bahkan oleh lembaga pendidikan Islam sendiri adalah literatur barat. Persepsi semacam itu sebenarnya adalah hal lumrah, karena memang sulitnya ditemukan literatur manajemen yang khas dunia Islam. ${ }^{1}$ Pemerintahan kabupaten/kota, Pemerintahan provinsi, dan Pemerintah juga memiliki tanggung jawab

\section{5).}

${ }^{1}$ Fahrurrozi, Manajemen Pendidikan Islam (Semarang: CV. Karya Abadi Jaya, 
untuk melakukan supervisi, pengawasan, evaluasi, fasilitasi, saran, arahan, dan/atau bimbingan kepada satuan/program pendidikan. ${ }^{2}$

Membangun karakter adalah bagian penting dari kinerja pendidikan. Sekolah sebagai lembaga pendidikan adalah salah satu sumber penting dalam menumbuhkembangkan kepribadian karakter seseorang. Saat mengevaluasi institusi pendidikan yang bersangkutan, penting untuk mengembangkan kurikukulum yang secara eksplisit mencakup pendidikan karakter. Karakter individu di akui tidak dapat dibentuk hanya melalui satu atau dua kegiatan saja, kemudian menyiapkan rancangan program pembangunan berkelanjutan dan karakter terpadu dalam pembelajaran, dimana prosesnya juga melibatkan semua guru, staf, dan lembaga lainnya di lembaga pendidikan, sehingga manfaat dari pembentukan karakter dapat diratakan. Saat ini pesantren dipandang masyarakat sebagai lembaga pendidikan yang mampu memberikan dan mengajarkan pendidikan karakter bagi santrinya. Dalam dunia pesantren, akhlak merupakan prioritas yang perlu diterapkan pada diri santri. Pesantren merupakan sub kultur Islam yang mengakar pada kebudayaan Islam di Indonesia. Pendidikan di pesantren tidak hanya terdapat sarana dan praktik pendidikan saja, pesantren juga menanamkan nilai norma. ${ }^{3}$ Nilai-nilai pendidikan karakter yang perlu ditanamkan pada diri santri atau santri antara lain: taqwa terhadap Tuhan Yang Maha Esa, toleransi, disiplin, kerja keras, kreatif, mandiri, demokrasi, rasa ingin tahu, semangat kebangsaan, cinta tanah air, menghargai prestasi, bersahabat/komunikatif, cinta damai, gemar membaca, peduli lingkungan, dan tanggung jawab. ${ }^{4}$ Misalnya dalam peraturan yang telah ditetapkan dan disepakati di awal pendaftaran. Salah satunya adalah berangkat sekolah tepat waktu, masuk kelas pukul 06.45 (santri putra) maka, jika telat akan diberikan sanksi atau hukuman bermaterai (sangsi yang diberikan ketika melanggar sebuah peraturan).

\footnotetext{
${ }^{2}$ Nanang Fattah, Sistem Penjaminan Mutu Pendidikan Dalam Konteks Penerapan MBS (Remaja Rosdakarya, 2012).

${ }^{3}$ M Chatib Thaha, "Strategi Pendidikan Islam Dalam Mengembangkan Manusia Indonesia Yang Berkualitas," in Makalah Seminar Oleh KMA-PBS IAIN Walisongo, Semarang, 1990.

${ }^{4}$ Kementerian Pendidikan Nasional, "Badan Penelitian Dan Pengembangan Pusat Kurikulum," Pengembangan Pendidikan Budaya Dan Karater Bangsa. Pedoman Sekolah, 2010.
} 
Setiap lembaga pendidikan memiliki strategi untuk meningkatkan mutu sekolah. Namun, dari cara-cara peningkatan mutu tersebut fokusnya akan berbeda. Di sini peneliti mengambil sample dari Yayasan Pendidikan Raudlatul Ulum Guyangan Trangkil Pati. Di lembaga pendidikan ini posisi paling tinggi adalah KH. M Najib Suyuthi M. Ag, sebagai pengasuh dan juga beliau adalah putra terakhir dari pendiri pesantren yaitu Almaghfurullah KH. Suyuthi Abdul Qodir (Mbah Suyuthi) setelah wafatnya 2 putra mbah Suyuthi yang pernah memegang lembaga pada periode-periode sebelumnya yaitu KH. Salim Suyuthi dan KH. Humam Suyuthi.

Madrasah Raudlatul Ulum Guyangan Pati merupakan sekolah yang terkenal di Kabupaten Pati, selain karena kualitas pendidikannya juga karena kedisiplinannya antara lain on time dalam segala hal, termasuk on time dalam memasuki kelas juga on time dalam menaati peraturan. Sanksi yang diberikan kepada santri yang melanggar peraturan adalah menulis surat bermaterai, untuk pelanggaran pertama dan kedua masih bisa ditoleransi, namun untuk pelanggaran ketiga santri tidak akan naik kelas, begitupun dengan pelanggaran ke empat maka akan dikeluarkan dari sekolah, dan apabila ada santri yang membawa HP, maka akan dikeluarkan dan dipulangkan. Sehingga setiap santri harus berupaya untuk tetap bertahan melawan segala peraturan untuk mendapatkan ilmu yang berkah, seperti syair dalam kitab Ta'limul Muta'allim karya Syekh Imam Burhanul Islam Azzarnuji

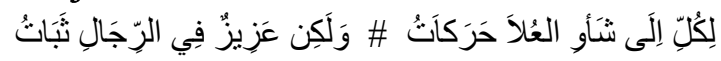

"Setiap orang berupaya untuk menggapai kedudukan yang tinggi. Tetapi jarang sekali dikalangan orang-orang itu yang bertahan"

Berbagai peraturan itulah yang membuat peneliti ingin meneliti di Madrasah tersebut. Sedangkan santri dan siswinya tergolong tidak sedikit, jumlah keseluruhan siwa dan siswi Madrasah Raudlatul Ulum mencapai sekitar 5000 lebih mulai dari Raudlatul Athfal sampai Madrasah Aliyah. Dan peraturan tersebut sudah dimulai sejak berdirinya sampai sekarang masih berkembang bahkan bisa dikatakan semakin banyak peraturan maka santri semakin disiplin.

Penjaminan mutu pendidikan formal, nonformal, dan informal sebagaimana tersurat dalam Peraturan Menteri Pendidikan Nasional

${ }^{5}$ Eka Ismawati, "Nilai-Nilai Sikap Guru Dan Murid Menurut Az-Zarnuji Dalam Bukunya Ta' limul Muta' allim" (UIN Raden Intan Lampung, 2017). 
Nomor 63 Tahun 2009 tentang Sistem Penjaminan Mutu Pendidikan, merupakan kegiatan yang sistemik dan terpadu pada penyelenggaraan pendidikan untuk meningkatkan tingkat kecerdasan kehidupan bangsa. Kegiatan yang sistemik dan terpadu tersebut dilakukan oleh satuan/program pendidikan, penyelenggara satuan/program pendidikan, pemerintah daerah, Pemerintah, dan masyarakat serta melibatkan dunia usaha.

Kedisiplinan di sini sangat mempengaruhi mutu pendidikan karena setiap santri yang disiplin dan patuh peraturan, secara otomatis manajemennya itu teratur, dari masuk kelas yang harus on time, atribut seragam yang harus lengkap, sampai hafalan yang setiap semester wajib diselesaikan.

\section{METODE PENELITIAN}

Jenis penelitian yang akan digunakan dalam penelitian ini ialah metode penelitian kualitatif. Yang bertujuan untuk memahami suatu fenomena yang sedang terjadi yang diamati oleh peneliti. Penelitian ini akan dilaksanakan di Madrasah Raudlatul Ulum Guyangan Pati. Madrasah Raudlatul Ulum merupakan salah satu lembaga pendidikan di bawah naungan Yayasan yang tidak hanya dalam bentuk sekolahan namun juga terdapat pondok pesantren, yayasan ini didirikan oleh $\mathrm{KH}$. Suyuthi Abdul Qodir, setelah wafatnya beliau yayasan pernah dipegang oleh dua orang anaknya yang telah wafat juga yaitu KH. Salim Suyuthi dan KH. Humam Suyuthi, dan sekarang yayasan dipegang oleh anak terakhir Mbah Suyuthi yaitu KH. Najib Suyuthi. Madrasah Raudlatul Ulum berada disebuah desa kecil desa Guyangan di kabupaten Pati Kecamatan Trangkil. Waktu yang digunakan oleh peneliti untuk melakukan penelitian yakni pada bulan Desember 2018.

Penjaminan mutu di Madrasah Aliyah Raudlatul Ulum melalui kedisiplinan yang menjadi mutu unggulan, diantaranya: kedisiplinan belajar, kedisiplinan masuk kelas, kedisiplinan atribut seragam, setoran hafalan, dan peraturan-peraturan lainnya. Alasan penulis meneliti di sana karena aturan-aturannya yang ketat dan disiplin, sebanyak kurang lebih 5000 santri itu mematuhi peraturan yang telah disepakati sejak awal bisa telaksana dengan baik, meskipun terdapat beberapa santri yang melanggar, namun setiap tahun santri semakin bertambah banyak. 
Dalam penelitian ini, peneliti menggunakan beberapa teknik dalam mengumpulkan data. Adapun teknik yang digunakan adalah wawancara dan obeservasi. Wawancara merupakan sebuah proses interaksi komunikasi yang dilakukan oleh setidaknya dua orang atas dasar ketersediaan, di mana arah pembicaraan mengacu kepada tujuan yang telah ditetapkan. ${ }^{6}$ Menurut Sutrisno Hadi (1986) yang dikutip oleh Sugiyono mengemukakan bahwa, observasi merupakan suatu proses yang kompleks, suatu proses yang tersusun dari pelbagai proses biologis dan psikologis. Dua diantara yang terpenting adalah proses-proses pengamatan dan ingatan. Pelaksanaan observasi di kantor TU dan Kepala Sekolah. Dengan metode observasi, peneliti dapat mengamati aktifitas dan perilaku individu-individu secara langsung sehingga peneliti dapat mendeskripsikan lingkungan yang diamati. ${ }^{7}$ Dalam penelitian ini, peneliti melakukan teknik observasi partisipasi, karena dalam observasi partisipasi pengumpulan data melalui observasi terhadap objek pengamatan dengan langsung hidup bersama, merasakan serta berada dalam aktivitas kehidupan objek pengamatan. Dengan demikian, pengamat betul-betul menyelami kehidupan objek pengamatan dan bahkan tidak jarang pengamat kemudian mengambil bagian dalam kehidupan budaya mereka. ${ }^{8}$

Dengan metode ini peneliti dapat memperoleh data dan informasi secara tertulis atau gambar yang berkaitan dengan masalah yang diteliti dan dapat dijadikan penguat dari metode dan wawancara observasi. ${ }^{9}$ Data yang telah diperoleh peneliti perlu diuji keabsahannya, yaitu dengan teknik triangulasi. Teknik ini dikenal dengan cek dan ricek, pengecekan dilakukan dengan tujuan apakah data yang diperoleh dengan beragam sumber teknik dan waktu memiliki kecocokan atau tidak. ${ }^{10}$

${ }^{6}$ Haris Herdiansyah, "Wawancara, Observasi, Dan Focus Groups: Sebagai Instrumen Penggalian Data Kualitatif," Jakarta: PT Raja Grafindo Persada, 2013.

${ }^{7}$ Herdiansyah.

${ }^{8}$ Burhan Bungin, "Analisis Data Penelitian Kualitatif," 2007.

${ }^{9}$ Rully Indrawan and R Poppy Yaniawati, "Metodologi Penelitian Kuantitatif," Kualitatif, Dan Campuran Untuk Manajemen, Pembangunan, Dan Pendidikan, Bandung: Penerbit PT Refika Aditama, 2014.

${ }^{10}$ Nusa Putra, "Penelitian Kualitatif: Proses Dan Aplikasi," Jakarta: Indeks, 2011. 


\section{HASIL DAN PEMBAHASAN PENELITIAN}

Menurut Yi Najib mengatakan "bahwa memang sebuah lembaga pendidikan pasti mempunyai visi dan misi agar lembaganya berjalan dengan baik sesuai dengan tujuan pendidikan, maka perlu sekali untuk merencanakan hal-hal yang berkaitan dengan mutu kedisiplinan". Sedangkan visi pesantren ialah "Selangkah lebih maju dalam prestasi dengan ilmu amaly dan amal ilmy", dari visi tersebut diharapkan untuk membuat santri dan siswi bisa menjadi bermutu dengan sedikit demi sedikit prestasi yang diperoleh dari pembelajaran yang didapat setiap harinya baik ilmu agama maupun ilmu umum, namun tidak lupa juga diiringi dengan akhlak yang bagus, karena seperti yang pernah dikatakan Yi Najib ketika pidato di depan santri, guru dan karyawan, bahwasannya "Adab seorang santri adalah akhlak, sepintar apapun seorang santri kalau tidak punya akhlak kepada orang tua, guru, dan orang-orang yang lebih tua, maka rugilah kamu. Untuk apa ilmumu?"11. Sedangkan implementasi manajemnen peningkatan mutu sekolah mempunyai tujuan sebagai berikut:

1) Meningkatkan mutu pendidikan melalui peningkatan kemandirian, fleksibilitas, partisipasi, keterbukaan, kerjasama, akuntabilitas, suistanbilitas, dan inisiatif madrasah dalam mengelola daya yang tersedia.

2) Meningkatkan kepedulian warga madrasah dan masyarakat dalam penyelenggaraan pendidikan melalui pengambilan keputusan bersama.

3) Meningkatkan tanggungjawab madrasah kepada orangtua, masyarakat dan pemerintah untuk meningkatkan mutu madrasah.

4) Meningkatkan kompetisi yang sehat antar madrasah dalam meningkatkan kualitas pendidikan. ${ }^{12}$

Menurut salah satu guru Madrasah Aliyah sekaligus Kepala Madrasah Ibtidaiyyah Pesantren Raudlatul Ulum Drs. Misbahul Munir mengatakan, "Alhamdulillah, pelaksanaan sudah sesuai standar mutu kedisiplinan yang telah terencana sesuai visi misi yang telah

${ }^{11}$ Wawancara dengan KH. Najib Suyuthi M.Ag, pengasuh sekaligus Kepala Madrasah Aliyah Raudlatul Ulum Guyangan Pati, 27 Januari 2019.

12 Prim Masrokan Mutohar, "Manajemen Mutu Sekolah," Jakarta: AR-Ruzz Media, 2013. 
direncanakan"13 santri dan siswi menaati peraturan dengan sebaikbaiknya, meskipun kedisiplinan yang mereka patuhi belum sepenuhnya dari hati, masih berupa tuntutan peraturan dan hukuman. Dari kedisiplinannya itulah, mutu yang direncanakan akan semakin meningkat jikalau adanya keterkaitan dan kesesuaian antara santri, guru dan karyawan sama-sama menaati peraturan. Peraturan yang nantinya membuat santri tersebut menjadi terlihat baik setelah menjadi alumnus dari Madrasah dan juga menjadi pesaing bagi sekolahan-sekolahan lain sehingga menjadi contoh aturan untuk peraturan-peraturn yang diterapkan di sekolah lain.

Sama halnya dengan Cindy Sukmawati, santri Madrasah Aliyah kelas sebelas jurusan IPA yang mengatakan, "saya dulu ketika belum masuk sekolah di sini melihat banyaknya aturan-aturan yang ditetapkan sangat takut, namun ketika saya sudah masuk bahkan sudah hampir 5 tahun saya di sini sejak kelas satu tsanawiyah saya merasa senang, merasa semakin baik karena saya sadar dengan beberapa pidato yang di paparkan oleh Yai bahwa kita harus berubah yaitu berubah menjadi lebih baik, dan perubahan kita nanti yang akan diuntungkan juga kita sendiri kelak". ${ }^{14}$

Menurut Yi Najib mengatakan bahwa, "kebijakan yang kami ambil dalam meningkatkan mutu adalah dengan menyamaratakan hak dan kewajiban semua warga Madrasah, tidak membeda-bedakan, apabila ada seorang santri bahkan guru maupun karyawan melanggar tata tertib/ peraturan Madrasah, tentu kami beri sangsi sesuai dengan kapasitasnya masing-masing". ${ }^{15}$ Setiap santri yang melanggar peraturan akan dikenakan sangsi yang sama. Dari beberapa peraturan yang ditetapkan dan harus dipatuhi antara lain:

1) Masuk kelas. Karena gedung yang dipakai untuk kegiatan belajar mengajar tidak sesuai dengan jumlah santri yang ada, jadi kegiatan belajar mengajar ada 2 waktu. Waktu pagi untuk santri putra masuk pukul 06.45 harus sudah berada di dalam kelas, dan pulang pukul 12.30 WIB. Sedangkan siangnya dipakai untuk siswi putri masuk

${ }^{13}$ Wawancara dengan guru sekaligus Kepala Madrasah Ibtidaiyyah Raudlatul Ulum Guyangan Pati, 28 Januari 2019.

${ }^{14}$ Wawancara dengan Cindy Sukmawati, Siswi Kelas XI MA Guyangan Pati, 31 Januari 2019.

15 Wawancara dengan KH. Najib Suyuthi M.Ag, pengasuh sekaligus Kepala Madrasah Aliyah Raudlatul Ulum Guyangan Pati, 27 Januari 2019. 
pukul 13.00 harus sudah berada didalam kelas dan pulang pukul 17.00. Apabila ada santri yang datang terlambat, maka santri harus membuat surat pernyataan bermaterai, apabila diulang kembali sampai 3 kali, maka santri tidak akan naik kelas dan apabila diulangi sampai 4 kali maka santri akan dikeluarkan dari sekolah. Dan perjanjian tersebut sudah disepakati antara orangtua, murid, dan pihak panitia pendaftaran serta ditandatangani di atas surat yang bermaterai.

2) Kedisiplinan setoran hafalan. Hafalan merupakan syarat wajib kenaikan kelas. Setoran hafalan dilakukan pada saat ujian tengah semester maupun akhir semester. Setoran hafalan dilakukan serentak di ruang perpustakaan disimak oleh guru-guru dan karyawan, dilakukan setelah mengerjakan ulangan selesai. Hafalan yang disetorkan harus lancar, apabila tidak lancar, maka harus mengulangi kembali. Setelah menghafalkan, maka kartu ditandatangani oleh guru atau karyawan penyemak, kartu diberikan sebelum semesteran dimulai bersama dengan diberikannya kartu ulangan. Dalam tiap semester, tengah semester atau akhir semester santri wajib menyetorkan hafalan 40-100 bait atau kurang lebih 200 bait dalam satu tahun. Bagi santri yang tidak menghafalkan, maka tidak akan naik kelas.

3) Kedisiplinan tidak membawa HP. HP di Raudlatul Ulum dihukumi haram bagi santri, karena tidak ada manfaatnya sama sekali jika HP dibawa di dalam kelas apalagi digunakan ketika pelajaran berlangsung. Bagi santri yang ketahuan membawa HP, maka akan langsung dikeluarkan dari sekolahan. Perjanjian tersebut sudah disepakati sejak awal santri mengisi formulir pendaftaran dan ditandatangani diatas surat bermaterai.

4) Kedisiplinan atribut. Selain beberapa aturan yang telah tertera di atas, masih ada beberapa peraturan yang harus dipatuhi termasuk kedisiplinan atribut, diantaranya harus memakai seragam lengkap beserta bet nya dan juga kaos kaki sesuai harinya. Kuku dan rambut tidak boleh panjang bagi laki-laki, dan bagi perempuan tidak boleh melampaui batas jilbab (rubuk) yang dipakai. Tidak boleh makan di 
dalam kelas. Dan peraturan-peraturan kondisional sesuai kegiatan masing-masing. ${ }^{16}$

Santri yang melanggar peraturan-peraturan tersebut, maka akan dihukum atau diberi sangsi yang sama, tidak ada perbedaan, baik anak pejabat maupun anaknya orang biasa. Seperti yang sering Yi Najib katakan ketika pidato di depan santri, guru maupun karyawan bahwa "berdiri sama tinggi dan duduk sama rendah" ${ }^{17}$. Dan Yi Najib pun tidak pernah mau menerima sumbangan dalam bentuk apapun dari walisantri. Semua pembayaran dibayarkan secara sama dan serentak. Sedangkan pelanggaran bagi guru dan karyawan yaitu ketepatan waktu masuk ke sekolahan dan seberapa sering guru tersebut izin, jadi agar tidak ada kecemburuan antara santri dan guru, maka ditetapkan juga untuk semua guru peraturan tersebut. Pengasuh akan mengeluarkan secara langsung guru yang jarang masuk ke kelas.

School plan yang dibuat untuk meningkatkan pendidikan di sekolah atau madrasah digunakan sebagai berikut: visi misi madrasah, identifikasi permasalahan (termasuk penyebab timbulnya permasalahan), prioritas permasalahan yang dihadapi madrasah untuk segera diselesaikan, alternatif cara yang dapat digunakan dalam memecahkan masalah, prioritas pemecahan permasalahan, tujuan program madrasah, Rencana Induk Pengembangan (RIP) Madrasah dalam jangka waktu tiga tahun sampai dengan lima tahun, sumber dana untuk membiayai program/kegiatan-kegiatan dalam rencana pengembangan madrasah, RAPBS yang memuat program/kegiatan dan anggaran dari semua sumber dalam jangka waktu satu tahun. ${ }^{18}$ Menurut Kepala Tata Usaha Mahmudi S.Kom bahwa "mengenai evaluasi, setiap saat kami selalu mengevaluasi mutu kedisiplinan demi terciptanya suasana pendidikan yang kondusif"19. Dari setiap evaluasi yang dilakukan, ada beberapa peraturan yang kurang dipatuhi santri yaitu makan di kelas, santri sering membawa makanan ringan atau semacam jajanan untuk dimakan bersama-sama atau bahkan terkadang kalau gurunya yang

\section{Tahun 2019}

16 Dokumentasi Pondok Pesantren Raudlatul Ulum Guyangan Trangkil Pati,

17 Wawancara dengan KH. Najib Suyuthi M.Ag, pengasuh sekaligus Kepala Madrasah Aliyah Raudlatul Ulum Guyangan Pati, 27 Januari 2019.

${ }^{18}$ Mutohar, "Manajemen Mutu Sekolah."

19 Wawancara dengan Mahmudi S.Kom, Kepala Tata Usaha Madrasah Aliyah Raudlatul Ulum, 28 Januari 2019. 
mengajar sudah tua yaitu guru yang mengampu pelajaran-pelajaran kitab kuning selalu diremehkan oleh santri, sehingga santri berani untuk makan dikelas saat pelajaran sekalipun. Peraturan lain yang masih sering dilanggar adalah banyak santri yang tidak memakai kaos kaki atau memakai kaos kaki tetapi tidak sesuai dengan jadwal harinya, seperti ini sering terjadi di kelasnya laki-laki, lalu ada juga kuku maupun rambutnya panjang, bagi laki-laki biasanya kuku jempol atau kelingking yang sering panjang kemudian banyak juga rambut yang sudah panjang dan tidak segera dicukur bahkan ada yang sampai disemir rambutnya. Sangsi seperti tersebut, maka rambut langsung digundul pada waktu itu juga. Sedangkan bagi perempuan, terkadang kukunya ada yang panjang semua karena mengikuti zaman, dan juga rambutnya ada yang sampai melewati kerudung, maka yang seperti inilah juga bisa dipotong langsung ketika ada pemeriksaan. ${ }^{20}$

Forecasting (peramalan), perencanaan harus dapat meramalkan, memperkirakan waktu yang akan datang tentang keadaan pendidikan, perkembangan situasi pelanggan, kebijaksanaan pemerintah, dan lain sebagainya. Ramalan-ramalan untuk memperkirakan pendidikan di masa yang akan datang disusun secara sistematis dan berkesinambungan serta berusaha mendahului kondisi-kondisi pada waktu yang akan datang. ${ }^{21}$ Perencanaan yang sudah dirancang sedemikian rupa lalu diramalkan agar bisa tercapai dan dapat meningkatkan mutu tersebut dalam perkiraan waktu yang akan datang tentang keadaan pendidikan, sehingga perencanaannya bisa tercapai dengan baik. Menurut Yi Najib "kedisiplinan merupakan pilar utama dalam menjalankan roda pendidikan di Madrasah Raudlatul Ulum Guyangan Pati. Terhadap peserta didik dalam menerapkan kebijakan kami menggunakan langkah bijak yaitu: ketika peserta didik melanggar satu kali maka harus membuat surat pernyataan (apabila pelanggaran ringan cukup surat pernyataan tanpa materai, tetapi bila pelanggaran sedang atau bahkan berat, maka membuat pernyataan untuk tidak mengulangi lagi bermaterai). Apabila sudah melanggar 2 kali, maka orangtua/wali kami beritahu melalui surat agar orangtua/wali ikut membenahi anaknya. Sedangkan apabila sudah 3 kali melanggar dalam kurun satu tahun maka peserta didik tersebut calon tidak naik kelas. Apabila dalam kurun satu

\footnotetext{
${ }^{20}$ Observasi di Yayasan Pesantren Raudlatul Ulum, 29 Januari 2019.

${ }^{21}$ Mutohar, "Manajemen Mutu Sekolah."
} 
tahun melanggar 4 kali, maka peserta didik tersebut diserahkan kembali kepada orangtua/wali. Lain halnya dengan pelanggaran yang mengenai HP, Laptop dan sejenisnya, satu kali saja langsung diserahkan kembali kepada orangtua/wali".22

Establishing objectives (penetapan tujuan). Kepala madrasah harus menentukan dengan tegas hasil akhir yang diinginkan. Menetapkan tujuan merupakan tugas dari perencana (planner), yaitu manajer atau pemimpin lembaga pendidikan. Tujuan harus dikembangkan untuk menentukan semua kegiatan yang akan dilakasnakan. Tanpa adanya tujuan yang jelas dan tegas, tidak akan mungkin bisa menghasilkan perencanaan yang bagus dan implementatif dalam meningkatkan mutu pendidikan. ${ }^{23}$ Setelah diramalkan dan diperkirakan waktunya, kemudian ditetapkan tujuan yang jelas dan tegas. Supaya adanya kedisiplinan dan aturan-aturan tersebut menjadi teratur, waktu yang dilakukan tidak terbuang-buang sia-sia. Juga mengajarkan akhlak yang bagus, bagaimana menghormati guru, orangtua dan orang yang lebih tua. Dari beberapa peraturan yang telah ditetapkan untuk mengajarkan santri bagaimana melakukan sesuatu dengan on time dan menghargai waktu dengan sebaik-baiknya. Seperti yang dikatakan Pak Mahmudi "santri di sini dituntut untuk menjadi lebih baik dengan akhlak dan prestasi, baik ilmu amaly dan amal ilmy"24. Dari situlah ilmu yang didapat dari madrasah bukan hanya imu dunia saja, namun juga mendapatkan asupan lebih pelajaran agama termasuk belajar caranya maknani kitab dengan menggunakan huruf arab pegon(huruf hijaiyyah tanpa ada harokat yang terkenal di Jawa).

Programming (pemrograman) perencanaan dalam meningkatkan mutu pendidikan harus menetapkan prosedur kegiatan-kegiatan dan pembiayaan yang diperlukan untuk setiap kegiatan demi tercapainya tujuan yang telah ditetapkan. Kepala Madrasah sebagai manajer pendidikan dapat memperkuat langkah-langkah tindakan yang akan diambil berdasarkan prioritas pelaksanaannya. Prioritas ini penting agar

${ }^{22}$ Wawancara dengan KH. Najib Suyuthi M.Ag, pengasuh sekaligus Kepala Madrasah Aliyah Raudlatul Ulum Guyangan Pati, 27 Januari 2019.

${ }^{23}$ Mutohar, "Manajemen Mutu Sekolah."

${ }^{24}$ Wawancara dengan Mahmudi S.Kom, Kepala Tata Usaha Madrasah Aliyah Raudlatul Ulum, 28 Januari 2019. 
tujuan bisa tercapai secara efektif. ${ }^{25}$ Setelah tujuan ditetapkan kemudian dikuatkan dengan program-program yang sudah dirumuskan antara lain program mata pelajaran kitab yang menjadikan beda dengan sekolah lain: Fath Al-Wahhab (Fiqh), Tafsir Al-Jalalain (Tafsir), Tajrid Al-Sharih (Hadis), Maraqi Al-Ubudiyyah (Akhlaq), Tarikh Al-Tasyri' Islamy(Sejarah Islam), Ghoyat Al-Wushul (Ushul Fiqh), Uqud Al-Juman (Balaghoh), Fath Al-Rauf Al Mannan (Ilmu Falak), Al-Asybah Wa An-Nadhir (Qowaid AlFiqhiyyah), Minhat Al-Mughits (Musthola Hadis), Ilmu Tafsir Al-Suyuthi (Ilmu Taafsir), Idhahu Al-Mubham (Mantiq) ${ }^{26}$ Muatan yang masih utuh dan asli, lalu dijumlah dengan kurikulum lainnya sehingga total 32 mata pelajaran. "ini tentu sangat berat, meski demikian insyaallah ini tidak memberatkan dan menjadi beban sepanjang para santri memiliki komitmen dan kesungguhan. Saya sering katakan pada anak-anak, man jadda wajada (siapa sungguh-sungguh, akan sukses)" pungkasnya Yi Najib. ${ }^{27}$

Scheduling (penjadwalan), Kepala Sekolah harus dapat menentukan waktu yang tepat dalam merencanakan program-program pendidikan yang strategis. Manajer menentukan waktu dari kegiatankegiatannya melalui penyusunan jadwal, kapan harus dimulai dan berapa lama setiap aktivitas atau program-program kegiatan dalam pendidikan dan pembelajaran di Madrasah bisa dilaksanakan dan dipertanggungjawabkan dengan baik. ${ }^{28}$ Kegiatan belajar mengajar dimulai pukul 06.45 pagi sampai pukul 17.00 yang diawali santri putra berangkat pagi sampai pulang pukul 12.30 siang kemudian dilanjutkan siswi putri berangkat siang ba' da dzuhur pukul 13.00 sampai sore. Pada jam tersebut peraturan berlaku dan apabila dilanggar, maka dikenakan sangsi yang telah ditetapkan masing-masing kesalahan. Bahkan berangkat les dan kegiatan-kegiatan kondisional seperti karantina bagi santri kelas XII yang akan menempuh ujian dan kegiatan-kegiatan seperti haul akbar, semua peraturan diperlakukan. ${ }^{29}$ Seperti yang dikatakan Cindy Sukmawati yang mengatakan "peraturannya tetap berlaku bagi

\footnotetext{
${ }^{25}$ Mutohar, "Manajemen Mutu Sekolah."

${ }^{26}$ Dokumentasi Pondok Pesantren Raudlatul Ulum Guyangan Trangkil Pati, Tahun 2019

${ }_{27}$ Wawancara dengan KH. Najib Suyuthi M.Ag, pengasuh sekaligus Kepala Madrasah Aliyah Raudlatul Ulum Guyangan Pati, 27 Januari 2019.

${ }^{28}$ Mutohar, "Manajemen Mutu Sekolah."

${ }^{29}$ Observasi di Yayasan Pesantren Raudlatul Ulum, 29 Januari 2019.
} 
semua kegiatan, semisal les pagi itu terhitung seperti masuk sekolah biasa, jadi semisal saya tidak berangkat, maka harus ada surat izin yang jelas agar tidak terkena materai. Begitupun ketika ada kegiatan-kegiatan di luar jam pelajaran seperti ekstrakurikuler maupun ko-kurikuler semua tetap diberlakukan peraturan yang bersangsi". ${ }^{30}$

Budgetting (penganggaran), juga merupakan alat pengendalian dalam sistem manajemen keuangan. Penganggaran yang disesuaikan dengan perencanaan program-program kegiatan di lembaga pendidikan akan dapat membantu pelaksanaan program dan pembiayaan yang ada di madrasah atau di lembaga-lembaga pendidikan lainnya. ${ }^{31}$ Jadwal kegiatan yang telah ditetapkan dan dilaksanakan semuanya di anggarankan. Anggaran madrasah berasal dari dana santri dan BOS. Pihak madrasah tidak menerima sumbangan dalam bentuk apapun, untuk mengurangi adanya kecemburuan antar santri maupun wali santri. Sehingga tidak menyebabkan yang mampu bisa ditempatkan di kelas khusus, dan yang kurang mampu berada di kelas terpencil, tutur Pak Misbah. ${ }^{32}$ Langkah-langkah tersebut sudah diterapkan sudah berpuluh puluh tahun dan tidak ada santri maupun orangtua/wali yang melakukan protes, karena mereka berfikir malah menjadi baik jikalau dilakukan halhal atau peraturan serta sangsi tersebut. Aturan-aturan yang ditetapkan yang mencakup: kedisiplinan masuk kelas, kedisiplinan setoran hafalan, kedisiplinan tidak membawa HP, kedisiplinan aribut seragam, kelengkapan atribut bet, kesesuaian kaos kaki sesuai jadwal, tidak memanjangkan kuku, tidak boleh memanjangkan rambut. Dari beberapa aturan yang telah ditetapkan, santri memberikan tanggapan positif. Dan tidak ada santri, guru maupun karyawan yang merasa dilakukan tidak adil.

Evaluasi dilakukan untuk mengukur dan menilai ketercapaian tujuan, hal tersebut merupakan tingkat ketercapaian standar. Kegiatan ini dilakukan untuk mengetahui kesenjangan dan permasalahan yang terjadi di sekolah dalam upaya memenuhi standar yang telah ditetapkan. pada kasus penjaminan mutu sekolah, evaluasi dapat dilakukan oleh

\footnotetext{
Januari 2019.

${ }^{31}$ Mutohar, "Manajemen Mutu Sekolah."

32 Wawancara dengan Misbahul Munir guru sekaligus Kepala Madrasah Ibtidaiyyah Raudlatul Ulum Guyangan Pati, 28 Januari 2019.
}

${ }^{30}$ Wawancara dengan Cindy Sukmawati, Siswi Kelas XI MA Guyangan Pati, 31 
Kepala Sekolah atau tim yang dibentuk oleh Kepala Sekolah. ${ }^{33}$ Ada beberapa masalah dari Madrasah yang masih perlu untuk dievaluasi, diantaranya:

a. Kurangnya guru untuk mengajar, sehingga kedisiplinan santri pun juga kurang dikarenakan minatnya santri hanya karena guru yang selalu sama. Dari jumlah guru Madrasah Aliyah yang mengajar santri putra maupun santri putri. Terhitung masih kurang dilihat dari banyaknya santri yang setiap kelas ada 50 santri dan setiap angkatan terhitung sekitar ada 10 kelas sehingga 3 angkatan ada sekitar 30 kelas yang harus diajar oleh guru dengan jumlah yang terbilang sedikit. Hal seperti itulah yang menyebabkan santri akan merasa menyepelekan guru karena sudah mengetahui karakter gurunya masing-masing. Belum lagi dengan gaji atau upah yang sering disebut bisyaroh sangat kurang mencukupi. Seperti yang dikatakan Yi Akhyar guru sekaligus orang yang masih keluarga dari Yayasan, mengatakan "disini (Madrasah) memang guru juga dituntut disiplin seperti santrinya juga, berangkat sesuai jam masuk dan pulang sesuai jam pulang sekolahan, lalu kami harus mengajar dengan waktu yang singkat karena memang pelajaran yang ditawarkan juga sangat banyak, namun dengan waktu yang sebentar itu pula kami dituntut agar santri paham, agar santri bisa. Bisyaroh yang kami dapatkan tidak seberapa, namun alhamdulillah cukup untuk kebutuhan sehari-hari karena ini namanya barokah, ngalap barokahipun Mbah Suyuthi." ${ }^{34}$ Guru menjadi sumber utama bagi kemajuan santri itu sendiri, jikalau gurunya hanya sedikit dan gajinya pun tidak memadai, bagaimana kesungguhan pengajarannya bisa diandalkan. Jadi dari pihak sekolah sebaiknya juga menambah guru-guru yang berkompeten. Santri yang unggul dan bermutu berasal dari guru yang berkompeten.

b. Kurangnya gedung untuk kegiatan pembelajaran akan mengurangi sikap disiplin santri yang seharusnya kegiatan pembelajaran dilakukan di kelas malah dilakukan di aula yang sangat luas, sehingga suara guru tidak terdengar keras, dikarenakan kurangnya gedung yang dimiliki. Seluruh gedung yang dimiliki Yayasan ada 11 gedung,

${ }^{33}$ Ridwan Abdullah Sani, Isda Pramuniati, and Anies Mucktiany, "Penjaminan Mutu Sekolah" (Bumi Aksara, 2015).

${ }^{34}$ Wawancara dengan Yi Akhyar Royyan, guru sekaligus kelauarga Yayasan Madrasah Aliyah Raudlatul Ulum Guyangan Pati, 28 Januari 2019. 
diantaranya: Gedung sekretariat sebagai pusat informasi, Gedung baru atau pelangi untuk santri MA, bangunan hasil wakaf dari pemerintah Arab, Gedung panjang untuk santri MTs dan MA, Gedung Saleh Suwandi atau gedung hijau untuk santri MA kelas 10, gedung hasil wakaf dari Prof. Malaysia, Gedung putih digunakan untuk santri MTs, Gedung MI, Pondok Putra, Pondok Putri, Auditorium dan Perpustakaan , Gedung Koperasi, tempat pembelian seragam, kitab, buku, dan atribut seragam maupun tempat fotocopy., Rumah Sakit AsSuyuthiyyah yang berada di pinggir jalan raya dan disediakan gratis bagi santri. ${ }^{35}$ Santri merasa malas untuk mengikuti pelajaran, karena kelas yang luas tempatnya di aula terkadang santri banyak yang tidur selain ruangannya yang cocok untuk tidur telentang juga tempatnya yang difasilitasi oleh kipas angin dan jendela terbuka sehingga angin juga masuk. Kurang lebih dari 5000 santri putra maupun putri, gedung yang dipakai untuk santri MA hanya ada 2 gedung yaitu gedung Baru dan gedung Saleh Suwandi, masing-masing berlantai 3 yang berjumlah ada 27 ruangan, dari gedung Baru ada 12 ruang atau kelas yang digunakan untuk kegiatan pembelajaran dan ada 3 ruangan yang digunakan untuk kantor guru, pusat informasi MA, dan Laboratorium Komputer. Sedangkan di gedung Saleh Suwandi ada 12 ruangan, 10 ruangan untuk dijadikan kelas dan kegiatan belajar mengajar lalu 2 ruangan digunakan ruangan ISRU (Ikatan Santri Raudlatul Ulum) atau biasa disebut ruangan OSIS, dan ruangan Laboratorium Bahasa. Jumlah kelas tersebut sangat kurang memadai sehingga menyebabkan santri putra dan santri putri harus dibedakan jam masuknya, yaitu pagi dan siang. Terkadang karena batas waktu dan gedung yang sangat kurang memadai santri ada yang kelasnya di Aula tanpa ada meja dan kursi, dan setiap pagi bagi siswi putri ada tambahan pelajaran atau biasa disebut les namun sebenarnya pelajaran asli yang bertempat di Ndalem Mbah Suyuthi, begitupun dengan santri putra di sore hari ketika siswi putri berangkat sekolah di siang hari. Dari hal-hal tersebut seharusnya gedung mulai ditambah meskipun biaya yang dianggarkan juga tidak sedikit karena santri setiap tahun semakin bertambah banyak yang mendaftar. Sehingga penjaminan mutu yang ditawarkan oleh pihak Madrasah semakin membaik, karena

35 Dokumentasi Pondok Pesantren Raudlatul Ulum Guyangan Trangkil Pati, Tahun 2019 
bertambahnya kenyamanan yang dirasakan santri maupun pihak orangtua atau wali.

c. Kurangnya fasilitas yang diberikan. Diantaranya: setiap kelas tidak ada kipas maupun AC, setiap santri yang kepanasan harus membawa kipas sendiri baik berupa kertas atau kipas kecil, begitu juga dengan gurunya membawa kipas sendiri dari rumah. Selain itu proyektor atau LCD setiap kelas belum ada, proyektor disediakan oleh sekolahan hanya ada 3 untuk gantian dan harus antri antar kelas. Padahal proyektor merupakan salah satu alat yang sangat dibutuhkan untuk menunjang keberlangsungan proses pembelajaran. Sehingga tidak menggunakan metode sebelumnya dengan menulis manual atau menerangkan secara langsung. Santri sekarang dituntut agar mandiri, jadi guru cukup dengan memperlihatkan video pembelajaran dan santri dituntut untuk dapat menyimpulkan untuk didiskusikan bersama teman-temannya. Selain itu jug ada laboratorium komputer, laboratorium bahasa, dan aboratorium IPA yang belum cukup atau belum memadai. Laboratorium komputer jarang digunakan dikarenakan banyak komputer yang rusak, santri tidak bisa menggunakan komputer sehingga disalahgunakan untuk permainan bukannya untuk pelajaran informatika, dan jumlah komputer yang sedikit yang menyebabkan santri menggunakan laboratorium komputer seminggu sekali. Laboratorim bahasa juga banyak yang rusak, namun tidak separah Laboratorium komputer karena yang menggunakannya hanya jurusan bahasa atau pada saat pelajaran bahasa inggris untuk listening, laboratorium bahasa hanya ada satu, bahkan meskipun sudah masuk di laboratorium bahasa, santri hanya masuk tanpa menggunakannya, sedangkan guru membawa alat sendiri.

Laboratorium IPA fasilitasnya sangat belum layak, alat-alat yang digunakan dan disediakan belum lengkap, mikroskop nya juga tidak jelas, banyak alat-alat yang sudah berkarat, banyak yang pecah, karena jarang dipakai. Laboratorium IPA sangat jarang digunakan, semua tergantung guru IPA masing-masing jika ingin praktek. Selanjutnya, setelah data dideskripsikan langkah berikutnya dalam subbab ini yaitu data dianalisis. Dalam analisis dan atau pembahasan, penulis membahas tentang manajemen penjaminan mutu dalam meningkatkan kedisiplinan santri MA. Setiap sekolah/madrasah harus mempunyai school plan dalam 
meningkatkan mutu pendidikan. Perencanaan ini harus dibuat agar sekolah mempunyai rambu-rambu yang bisa dijadikan landasan dalam pelaksanaan program-program madrasah yang melibatkan partisipasi seluruh warga madrasah dan masyarakat. Hal ini dimaksudkan agar semua komponen tersebut dapat bekerja sama dalam mengembangkan madrasah dan mengetahui visi dan misi yang dimiliki oleh madrasah dalam meningkatkan mutu pendidikannya. ${ }^{36}$

Pelaksanaan penjaminan mutu dalam meningkatkan kedisiplinan tidak hanya dilakukan oleh santrinya saja namun guru dan staff pun ikut menaati peraturan supaya tidak terjadi kecemburuan antar santri, guru pun ikut mematuhi peraturan dengan baik, dan guru yang melanggar maupun telat juga mendapatkan sangsi berupa point atau menghadap langsung dengan pengasuh yayasan. Evaluasi dilakukan untuk mengukur dan menilai ketercapaian tujuan, yang dalam hal ini adalah tingkat ketercapaian standar. Kegiatan ini dilakukan untuk mengetahui kesenjangan dan permasalahan yang terjadi di sekolah dalam upaya memenuhi standar yang telah ditetapkan. Pada kasus penjaminan mutu sekolah, evaluasi dapat dilakukan oleh kepala sekolah atau tim yang dibentuk oleh kepala sekolah. ${ }^{37}$ Dalam evaluasi ini kepala sekolah sudah melaksanakan dengan baik, setiap kekurangan sekolahan sudah diatasi, namun ada beberapa kendala yang memang belum terselesaikan mengenai kurangnya guru dan kurangnya fasilitas ruangan. Ruangan kelas/ gedung belum terpenuhi sepenuhnya sehingga mengurangi pencapaian disiplin santri, ruang kelas yang seharusnya mumpuni untuk kegiatan belajar megajar terhambat karena kurangnya fasilitas dan santri pun merasa kurang nyaman, apalagi ruangan untuk penyetoran hafalan yang merupakan syarat wajib yang harus dipenuhi untuk kenaikan kelas. Manajemen seharusnya diatur sedemikian rupa sehingga guru tetap ada semua, setiap kelas selalu mendapatkan guru yang sama padahal gaji per bulannya bisa dikatakan pas atau bahkan kurang untuk ukuran kebutuhan hidup sehari-hari, namun karena keberkahannya, maka insyaallah cukup.

\footnotetext{
${ }^{36}$ Mutohar, "Manajemen Mutu Sekolah."

${ }^{37}$ Sani, Pramuniati, and Mucktiany, "Penjaminan Mutu Sekolah."
} 


\section{SIMPULAN}

Berdasarkan data hasil penelitian Manajemen Penjaminan Mutu Dalam Meningkatkan Kedisiplinan Santri di Madrasah Aliyah Raudlatul Ulum Guyangan Pati, selanjutnya akan disimpulkan sebagai berikut: Perencanaan manajemen mutu diatur sesuai visi dan misi agar lembaganya berjalan dengan baik sesuai dengan tujuan pendidikan, sedangkan visi pesantren ialah "Selangkah lebih maju dalam prestasi dengan ilmu amaly dan amal ilmy", dan juga ditambah dengan kedisiplinan yang tetapkan dengan aturan-aturan yang sudah dibuat sejak dulu yang dari itu santri dan juga yayasan terkenal karena begitu bagus sistem kedisiplinanya. Pelaksanaan dalam kedisiplinan peningkatan mutu yang dilakukan yayasan yaitu melalui aturan-aturan yang ditetapkan, yang mencakup kedisiplinan masuk kelas, kedisiplinan setoran hafalan, kedisiplinan tidak membawa HP, kedisiplinan aribut seragam, bet harus lengkap, kaos kaki harus sesuai hari, kuku tidak boleh panjang, rambut tidak boleh panjang, dan aturan-aturan yang berjalan secara kondisional sesuai kegiatan yang ada disekolahan. Evaluasi yang diperoleh dari perencanaan dan pelaksanaan yaitu kurangnya fasilitas yang tidak mumpuni sehingga mutu yang dijamin melalui kedisiplinan tersebut terhambat, salah satu contohnya adalah setoran hafalan yang dilaksanakan hanya disatu ruangan dan antrian yang panjang dan juga kurangnya guru untuk menyimak santri yang hafalan wajib untuk menjadi syarat kenaikan kelas.

\section{REKOMENDASI}

Berdasarkan kesimpulan-kesimpulan dari hasil penelitian yang telah dilaksanakan oleh penulis dan untuk meningkatkan mutu kedisiplinan Madrasah Aliyah Raudlatul Ulum Guyangan Pati, maka penulis akan memberikan saran, antara lain: Perencanaan seharusnya lebih ditekankan dari kedisiplinan bukan dari visi, misi karena visi dan misi sudah terlaksana dengan baik. Pelaksanaan untuk atribut seperti kuku panjang, memakai kaos kaki sesuai hari dan rambut santri laki-laki yang rambutnya disemir kurang ditekankan, seharusnya dilakukan pengecekan setiap saat atau sebelum masuk kelas. Evaluasi yang diambil seharusnya dilakukan penambahan guru dan ruang kelas/gedung. 


\section{DAFTAR PUSTAKA}

Bungin, Burhan. "Analisis Data Penelitian Kualitatif," 2007.

Fahrurrozi. Manajemen Pendidikan Islam. Semarang: CV. Karya Abadi Jaya, 2015.

Fattah, Nanang. Sistem Penjaminan Mutu Pendidikan Dalam Konteks Penerapan MBS. Remaja Rosdakarya, 2012.

Herdiansyah, Haris. "Wawancara, Observasi, Dan Focus Groups: Sebagai Instrumen Penggalian Data Kualitatif." Jakarta: PT Raja Grafindo Persada, 2013.

Indrawan, Rully, and R Poppy Yaniawati. "Metodologi Penelitian Kuantitatif." Kualitatif, Dan Campuran Untuk Manajemen, Pembangunan, Dan Pendidikan, Bandung: Penerbit PT Refika Aditama, 2014.

Ismawati, Eka. "Nilai-Nilai Sikap Guru Dan Murid Menurut Az-Zarnuji Dalam Bukunya Ta' limul Muta' allim." UIN Raden Intan Lampung, 2017.

Mutohar, Prim Masrokan. "Manajemen Mutu Sekolah." Jakarta: AR-Ruzz Media, 2013.

Nasional, Kementerian Pendidikan. "Badan Penelitian Dan Pengembangan Pusat Kurikulum." Pengembangan Pendidikan Budaya Dan Karater Bangsa. Pedoman Sekolah, 2010.

Putra, Nusa. "Penelitian Kualitatif: Proses Dan Aplikasi." Jakarta: Indeks, 2011.

Sani, Ridwan Abdullah, Isda Pramuniati, and Anies Mucktiany. "Penjaminan Mutu Sekolah." Bumi Aksara, 2015.

Thaha, M Chatib. "Strategi Pendidikan Islam Dalam Mengembangkan Manusia Indonesia Yang Berkualitas." In Makalah Seminar Oleh KMA-PBS IAIN Walisongo, Semarang, 1990. 